EESTI NSV TEADUSTE AKADEEMIA TOIMETISED. 21. KOIDE KEEMIA * GEOLOOGIA. 1972, NR. 4

ИЗВЕСТИЯ АКАДЕМИИ НАУК ЭСТОНСКОИ ССР. ТОМ 21 ХИМИЯ * ГЕОЛОГИЯ. 1972, № 4

удК $547.32 ; 66.095 .21$ К. ЛЭЭТС, СИГНЕ ТЕНГ

\title{
ОБ ИЗОМЕРИЗАЦИИ ТЕРПЕНОВЫХ ГАЛОГЕНОПРОИЗВОДНЫХ В ПРОЦЕССЕ КАТИОННОЙ ТЕЛОМЕРИЗАЦИИ
}

Судя по составу продукта теломеризации изопрена с его гидрохлоридами ['], галогенопроизводные в процессе реакции подвергаются аллильной перегруппировке, а также могут изомеризоваться нли циклизоваться.

В продолжение начатых исследований $\left[{ }^{1,2}\right]$ в области теломеризации изопрена с его гидрохлоридами нами осуществлено изучение изомеризации важнейших аллильных галогенопроизводных фракций $\mathrm{C}_{10}$ в процессе теломеризации. Нужные для этого чистые геранил-, нерил- и линалилхлориды синтезированы ранее [3, $]$. Теломеризация проводилась с эквимолярным раствором изопрена и хлорида в растворе дихлорэтана в присутствии безводного $\mathrm{SnCl}_{4}$. В полученном теломере определялось содержание хлора, а состав фракции $\mathrm{C}_{10}$ определялся новым методом газовой хроматографии, разработанным в нашей лаборатории [5].

Результаты исследования приведены в таблице. Молярные выходы продуктов реакции изомеризации, а также теломеризации (по содержанию галогена в теломере) от степени конверсии исходного терпенового галогенопроизводного приведены на рис. 1-3.

На основе приведенных зависимостей можно заключить, что наибольшая скорость аллильной изомеризации у линалилхлорида, дающая при степени конверсии $90 \%$ в основном смесь геранилхлорида, нерилхлорида и $\alpha$-терпинилхлорида с преобладанием первого. Наибольшая скорость циклизации у нерилхлорида, дающая при конверсии $50 \%$ в основном $\alpha$-терпинилхлорид. Скорость изомеризации геранилхлорида наименьшая, и в результате реакции образуется в основном теломер.

На основе полученных данных кинетическую схему реакции изомеризации можно представить в следующем виде

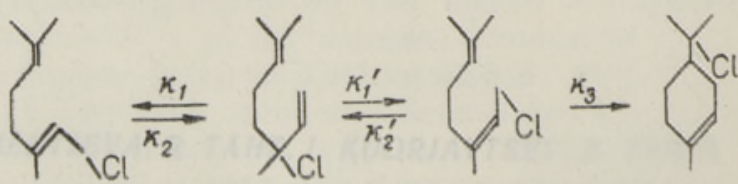

геранилхлорид линалилхл эрид нернлхлорид $\alpha$-терпинилхлорнд

При этом константы скорости реакции изомеризации располагаются в ряд: $\kappa_{1}>\kappa_{2} \ll \kappa_{3}$.

Установленные закономерности могут служить основанием для более полного познавания закономерностей реакций ионной теломеризации. 


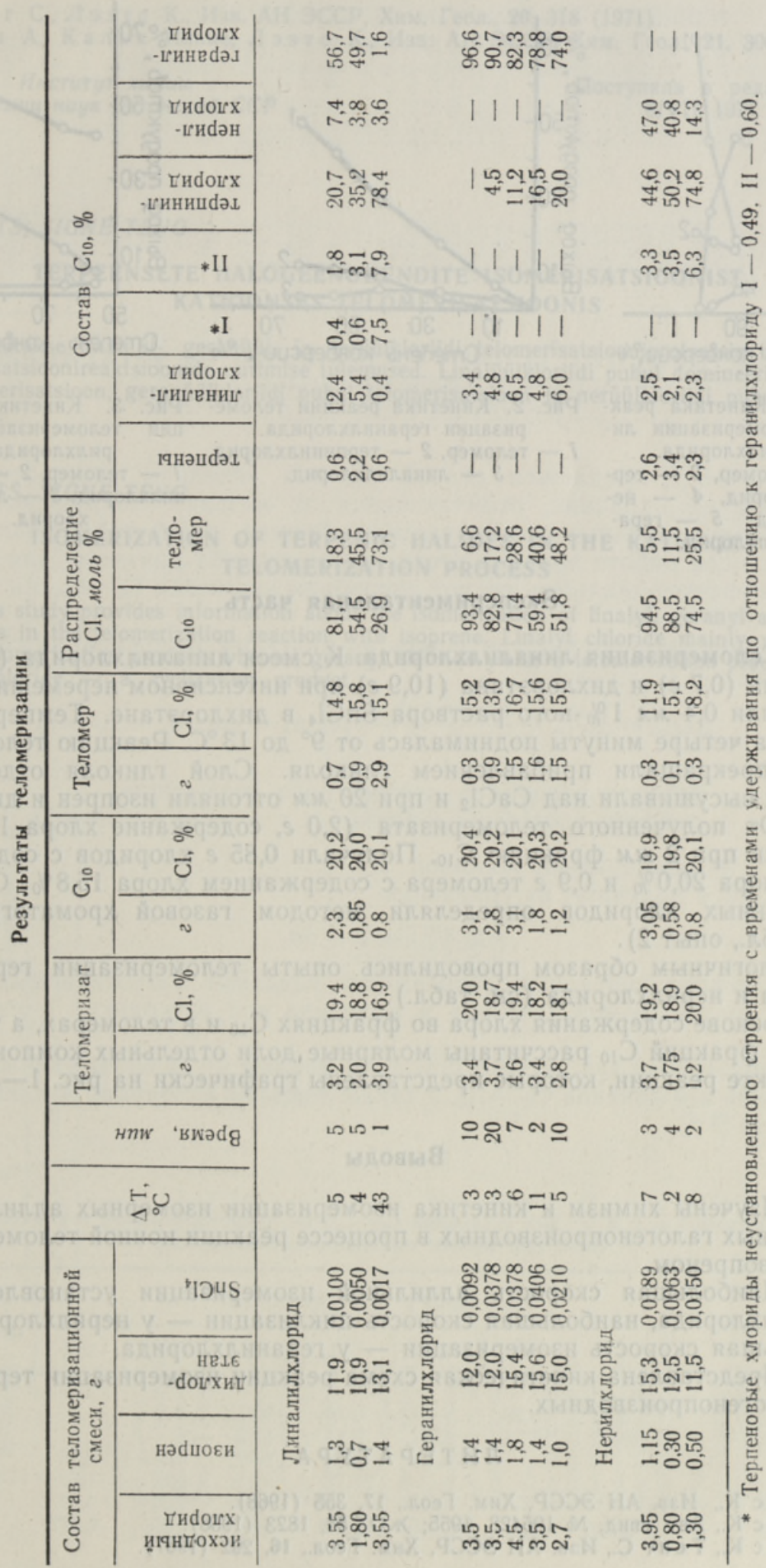




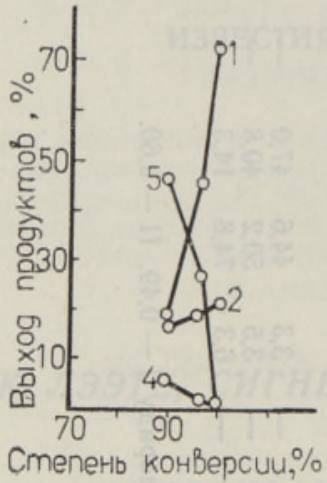

Рис. 1. Кинетика реакции теломеризации линалилхлорида.

1 - теломер, 2 - терпинилхлорид, 4 - нерилхлорид, 5 - геранилхлорид.

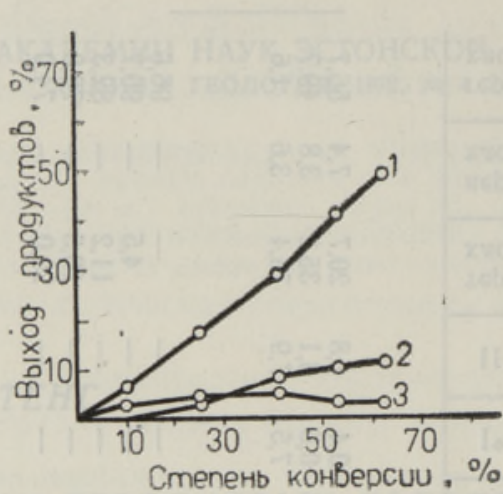

Рис. 2. Кинетика реакции теломеризации геранилхлорида.

I - теломер, 2 - терпинилхлорид, 3 - линалилхлорид.

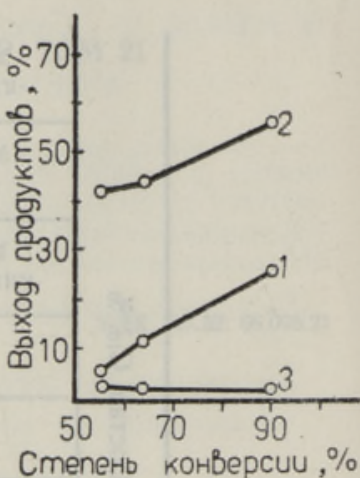

Рис. 3. Кинетика реакции теломеризации нерилхлорида,

1 - теломер, 2 - терпинилхлорид. 3 - линалилхлорид.

\section{Экспериментальная часть}

1. Теломеризация линалилхлорида. $\mathrm{K}$ смеси линалилхлорида $(1,8$ г), изопрена $(0,7$ 2) и дихлорэтана (10,9 г) при интенсивном перемешивании добавляли 0,4 мл 1\%-ного раствора $\mathrm{SnCl}_{4}$ в дихлорэтане. Температура смеси за четыре минуты поднималась от $9^{\circ}$ до $13^{\circ} \mathrm{C}$. Реакцию теломеризации прекращали прибавлением гликоля. Слой гликоля отделяли, остаток высушивали над $\mathrm{CaCl}_{2}$ и при 20 мм отгоняли изопрен и дихлорэтан. От полученного теломеризата (2,0 г, содержание хлора $18,8 \%$ ) отгоняли при 2 мм фракцию $\mathrm{C}_{10}$. Получали 0,85 г хлоридов с содержанием хлора 20,0\% и 0,9 г теломера с содержанием хлора 15,8\%. Состав перегнанных хлоридов определяли методом газовой хроматографии (см. табл., опыт 2).

Аналогичным образом проводились опыты теломеризации геранилхлорида и нерилхлорида (см. табл.).

На основе содержания хлора во фракциях $\mathrm{C}_{10}$ и в теломерах, а также состава фракций $\mathrm{C}_{10}$ рассчитаны молярные доли отдельных компонентов в продукте реакции, которые представлены графически на рис. $1-3$.

\section{Выводы}

1. Изучены химизм и кинетика изомеризации изомерных аллильных терпеновых галогенопроизводных в процессе реакции ионной теломеризации с изопреном.

2. Наибольшая скорость аллильной изомеризации установлена у линалилхлорида, наибольшая скорость циклизации - у нерилхлорида и наименьшая скорость изомеризации - у геранилхлорида.

3. Представлена кинетическая схема реакции изомеризации терпеновых галогенопроизводных.

\section{ЛИТЕРА Т У Р А}

1. Лээтс К., Изв. АН ЭССР, Хим. Геол., 17, 355 (1968).

2. Л э э т с К., Авт. свид. № 105428,1955 ; ЖоХ 58,1823 (1958),

3. Л э э тс К., Т ен г С., Изв. АН ЭССР, Хим. Геол., 16, 292 (1967), 
4. Т ен г С., Л э э т с К., Изв. АН ЭССР, Хим. Геол., 20, 318 (1971).

5. Э р м А., К а лья Ильме, Л ээ т с К., Изв. АН ЭССР, Хим. Геол., 21, 300 (1972).

Институт химии

Академии наук Эстонской ССР
Поступила в редакцию 6/VII 1971

\section{K. LAATS, SIGNE TENG}

\section{TERPEENSETE HALOGEENOHENDITE ISOMERISATSIOONIST KATIOONSES TELOMERISATSIOONIS}

Esitatakse linalüül-, geranüül- ja nerüülkloriidi telomerisatsiooniprotsessis toimuvate isomerisatsioonireaktsioonide uurimise tulemused. Linalüülkloriidi puhul domineerib allüülne isomerisatsioon, geranüülkloriidi puhul telomerisatsioon ja nerüülkloriidi puhul tsüklisatsioon.

\section{K. LAATS, SIGNE TENG}

\section{ISOMERIZATION OF TERPENIC HALIDES IN THE KATIONIC TELOMERIZATION PROCESS}

This study provides information about the isomerization of linalyl, geranyl and neryl chlorides in the telomerization reaction with isoprene. Linalyl chloride mainly yields an allylic isomerization product, whereas geranyl chloride yields a telomerization product, and neryl chloride - a cyclization product. 